\title{
CEREBRAL MASS LESION DUE TO CYTOMEGALOVIRUS IN A PATIENT WITH AIDS: CASE REPORT AND LITERATURE REVIEW
}

\author{
José E. VIDAL, Rafi F. DAUAR, Augusto C. PENALVA de OLIVEIRA, João F.G.S. COELHO \& Diogo L.M. LINS
}

\begin{abstract}
SUMMARY
Cytomegalovirus (CMV) disease in acquired immunodeficiency syndrome (AIDS) patients most commonly presents as chorioretinitis and gastro-intestinal infection. Neurological involvement due to CMV may cause several clinical presentations: polyradiculitis, myelitis, encephalitis, ventriculo-encephalitis, and mononeuritis multiplex. Rarely, cerebral mass lesion is described. We report a 39 year-old woman with AIDS and previous cerebral toxoplasmosis. She presented with fever, seizures, and vulval ulcers. Her chest X-ray showed multiple lung nodules, and a large frontal lobe lesion was seen in a brain computed tomography scan. She underwent a brain biopsy through a frontal craniotomy, but her condition deteriorated and she died in the first postoperative day. Histopathological studies and immunohistochemistry disclosed CMV disease, and there was no evidence of cerebral toxoplasmosis, bacterial, mycobacterial or fungal infection. CMV disease should be considered in the differential diagnosis of cerebral mass lesion in AIDS patients. High suspicion index, timely diagnostic procedures (surgical or minimally invasive), and proper utilization of prophylactic and therapeutic medication could improve outcome of these patients.
\end{abstract}

KEYWORDS: Cerebral mass lesion; Focal brain mass; Intracranial mass lesion; Focal neurological disease; Cytomegalovirus; Acquired immunodeficiency syndrome.

\section{INTRODUCTION}

Introduction of highly active antiretroviral therapy (HAART) has resulted in a dramatic improvement of the course and prognosis of acquired immunodeficiency syndrome (AIDS)-related disorders. In most developed countries and in Brazil, where treatment is widely available, it has dramatically reduced mortality in AIDS patients ${ }^{19}$. In HAART era, the occurrence of central nervous system opportunistic diseases, including cytomegalovirus encephalitis, also are decreasing ${ }^{14}$. However, neurological complications still remain an important cause of death and disability in human immunodeficiency virus (HIV)-infected patients ${ }^{14,30}$.

CMV disease in AIDS patients is a late event and its occurrence seems to be an independent predictor of death ${ }^{11}$. Besides retinitis, another five classical neurological presentations have been described: polyradiculitis, myelitis, encephalitis, ventriculoencephalitis, and mononeuritis multiplex ${ }^{4,13,15,18,20,21}$. Rarely, cerebral mass lesions due to CMV have been reported ${ }^{21}$.

We report a fatal case of CMV disease mimicking a central nervous system tumor in an AIDS patient and review of the literature.

\section{CASE REPORT}

A 39 year-old woman was diagnosed with cerebral toxoplasmosis and AIDS in July 1998. After treatment with sulfadiazine, pyrimetamine and folinic acid, there were complete radiological and clinical resolution, and she was discharged home.

In September 1998, the patient was readmitted with a 2-week history of fever, seizures, mild dificulty speaking and diminished psychomotor activity. Physical examination disclosed a pale and drowsy woman whose temperature was $38.2^{\circ} \mathrm{C}$. She had hepatosplenomegaly and vulval ulcers. The rest of the exam was unremarkable. Laboratory revealed hemoglobin $=9.7 \mathrm{mg} / \mathrm{dL}$, leukocytes $=2800$ cells $/ \mathrm{mm}^{3}(72 \%$ neutrophils, $15 \%$ lymphocytes, $13 \%$ monocytes). Biochemical tests disclosed AST $=32$ UI, ALT $=62$ UI, and alkaline phosphatase $=364$ UI. Chest radiograph showed disseminated nodular images. Chest CT scan confirmed this finding. A transbronchial lung biopsy was performed but was inconclusive. Brain CT scan showed a single left frontal lesion that enhanced heterogeneously circumscribed by intense edema and that shifted the midline (Fig. 1). Serological studies (IgG antibodies) for cytomegalovirus, Toxoplasma gondii, and herpes simplex virus virus were positive. CD4+ T-lymphocyte counts was 8 cells $/ \mu \mathrm{L}(2.8 \%)$. Fundoscopic examination was normal. The patient was treated with sulfadiazine, pyrimethamine, folinic acid, dexamethasone, and acyclovir. Three weeks after, the brain lesion showed just a slight decrease in perilesional edema. Nonetheless, the vulval lesions healed. She underwent a brain biopsy through a frontal craniotomy, but her condition deteriorated and she died in the first postoperative day due to disseminated 


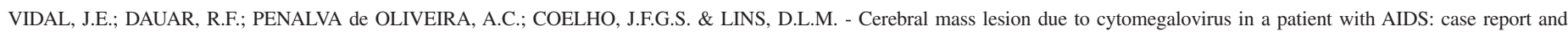
literature review. Rev. Inst. Med. trop. S. Paulo, 45(6):333-337, 2003.

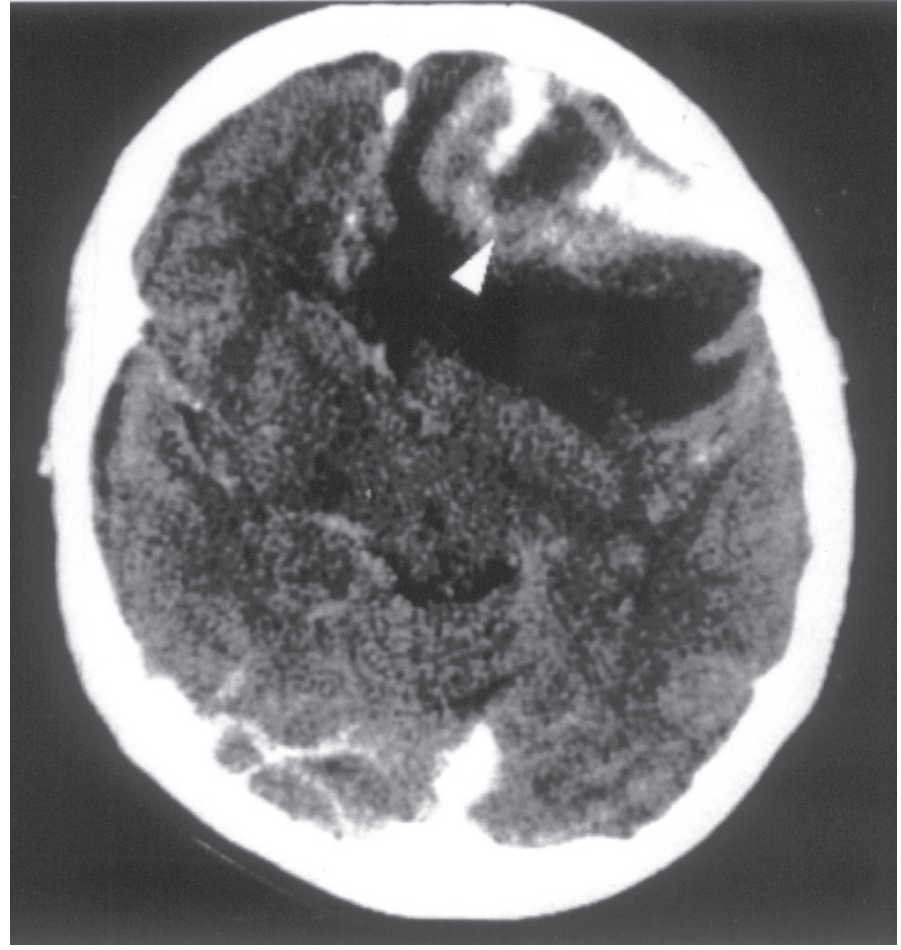

Fig. 1 - Cranial CT scan showing a large contrast-enhancing lesion in the left frontal area with extensive perilesional edema (arrow).

intravascular coagulation. Permission for autopsy was refused. Pathological examination of the brain biopsy showed a granulomatous inflammatory reaction, giant cells containing intra-cytoplasmatic and intra-nuclear inclusions. The involvement of central nervous system due to CMV was confirmed using immunohistochemistry. There was no evidence of toxoplasmosis, bacterial, mycobacterial or fungal disease.

\section{DISCUSSION}

In the AIDS era, we reviewed the literature from 1981 to 2002 using the MEDLINE database (National Library of Medicine, Bethesda, MD). Additionally, we also searched manually in journals. The key word used were cerebral mass lesions, focal brain lesion, intracranial mass lesion, cytomegalovirus, and acquired immunodeficiency syndrome.

We found only seven case reports of cerebral mass lesions due to $\mathrm{CMV}^{5,10,16,24}$. Table 1 lists the main features of these cases, including our patient.

Despite being extremely rare in the central nervous system, pseudotumoral forms of cytomegalic inclusion disease have already been described in the gastrointestinal tract ${ }^{12,28}$, laryn $x^{31}$, submandibular glands ${ }^{29}$, and lungs $\mathrm{s}^{22,23,27}$.

Histopathological studies have found CMV encephalitis in up to $30 \%$ of AIDS patients, but there is not a good clinical and pathological correlation $^{7,16,21,24}$. Moreover, no correlation was found between presence or severity of microglial nodules and ante mortem neurological cognitive impairment ${ }^{26}$.
Neurological presentation of intracranial mass due to CMV was similar to other causes of intracranial mass lesions, including cerebral toxoplasmosis and primary lymphoma central nervous system, the most common causes of cerebral mass lesions in AIDS patients. In some cases, this fact justified anti-toxoplasmic therapy, with the consequent diagnosis delay. For this reason, the history ${ }^{5,11,16}$ or concomitant CMV disease in another organ ${ }^{11,24}$ should be considered in the initial approach of patients with AIDS and focal brain lesions, and rise the suspicion index of CMV.

Current algorithms advise empirical treatment for T. gondii in AIDS patients with brain mass lesions ${ }^{2}$. Stereotactic biopsy is warranted if after 10-14 days of treatment there is no clinical or tomographic improvement. However, under some circumstances, this protocol may be curtailed, such as in cases of negative serological studies for T. gondii, single lesion on MRI or when therapeutically indicated ${ }^{2}$. Some of the reported cases were serologically negative for toxoplasmosis ${ }^{5,10,16}$. BASSIL \& WILLIAM ${ }^{5}$ reported a case where the patient had already suffered from CMV retinitis and whose serological studies were negative for toxoplasmosis. On the fifth hospital day, the patient underwent a stereotactic biopsy that confirmed a cerebral focal lesion due to CMV thus allowing early diagnosis and successful treatment. This case suggests that a high suspicion index should raise the possibility of early surgery.

Neuroimaging studies are usually unhelpful in diagnosis suspicion of intracranial mass in AIDS patients. The findings of cerebral mass lesions due to CMV are non specific and cannot be differentiated of another causes of intracranial mass lesions. Seven patients had single lesions ${ }^{5,10,16,24}$ and only one patient had two lesions. However, a previous CT scan had disclosed a single one ${ }^{24}$. Three patients had frontal lobe lesions ${ }^{10,24}$. Four patients had extensive lesions that enhanced and caused midline shift. One patient had a hemorrhagic lesion associated with a severe expansive effect ${ }^{10}$ and another one had just an increased focal attenuation coefficient, slight edema, and heterogeneous enhancement ${ }^{5}$.

CMV disease usually occurs in patients with very low CD4+ T-lymphocyte counts $(<50$ cell $/ \mu \mathrm{L})$. Similarly, the mean of CD4+ T-lymphocyte counts of patients with intracranial mass lesion due to CMV was 22 cells $/ \mu \mathrm{L}$ (range, 8 - 81 cells $/ \mu \mathrm{L}$ ).

In the last years, new techniques in imaging and molecular methods have been added to the management of AIDS patients suffering from brain focal lesions. This improvement has led to a reduction in the number of brain biopsies giving way to minimally invasive approaches ${ }^{1}$. Several research studies have demonstrated the value of the polymerase chain reaction (PCR) made in cerebrospinal fluid (CSF) for the diagnosis of CMV disease ${ }^{1,8,30}$. This test sensitivity varies from $33 \%$ to $100 \%$, and its specificity from $42 \%$ to $100 \%$. Most studies report sensitivity in excess of $80 \%$ and specificity higher than $90 \%^{30}$. Two of the reported cases were PCR reactive in $\mathrm{CSF}^{10,24}$. This approach is limited in cases where lumbar punctures are contraindicated, as in our case.

Some patients initially improved ${ }^{10,24}$ just to get worse later due to exacerbation or recurrence, pointing to the need of more prolonged treatment plans. However, two cases ${ }^{5,16}$ worsened in spite of the use of prophylactic oral ganciclovir. This finding coincides with another one drawn from a five patients study where usual doses of ganciclovir were incapable of avoiding or treating neurological complications when it is used primarily to treat chorioretinitis ${ }^{6}$. A small study of patients that 
Table 1

Details of reported cases of cerebral mass lesions due to cytomegalovirus in patients with AIDS

\begin{tabular}{|c|c|c|c|c|c|c|c|c|}
\hline $\begin{array}{l}\text { Patient } \\
\text { (Ref.) } \\
\text { [year] }\end{array}$ & Age / Sex & $\begin{array}{l}\text { Prior history } \\
\text { of CMV } \\
\text { infection }\end{array}$ & $\begin{array}{c}\text { Clinical } \\
\text { presentation }\end{array}$ & $\begin{array}{c}\text { Brain } \\
\mathrm{CT} / \mathrm{MRI}\end{array}$ & $\begin{array}{c}\text { CD4+ } \\
\text { cells / } \mu \mathrm{L}\end{array}$ & Diagnosis & Treatment & Outcome \\
\hline $\begin{array}{c}1 \\
(10) \\
{[1995]}\end{array}$ & $32 / \mathrm{M}$ & $\begin{array}{c}\text { Yes } \\
\text { (disseminated } \\
\text { disease) }\end{array}$ & $\begin{array}{l}\text { Fever, seizures, } \\
\text { bilateral limb } \\
\text { weakness }\end{array}$ & $\begin{array}{c}\text { Single } \\
\text { hemispheric } \\
\text { lesion }\end{array}$ & 81 & $\begin{array}{l}\text { Brain } \\
\text { biopsy }\end{array}$ & Ganciclovir & $\begin{array}{l}\text { Died } 3 \text { months } \\
\text { after diagnosis }\end{array}$ \\
\hline $\begin{array}{c}2 \\
(10) \\
{[1995]}\end{array}$ & $31 / \mathrm{M}$ & Not & $\begin{array}{c}\text { Fever, seizures, } \\
\text { confusion, } \\
\text { myelopathy, } \\
\text { Pneumonitis, retinitis }\end{array}$ & $\begin{array}{l}\text { Single } \\
\text { hemispheric } \\
\text { lesion }\end{array}$ & 14 & PCR on CSF & $\begin{array}{l}\text { Ganciclovir } \\
\text { and then } \\
\text { Foscarnet }\end{array}$ & $\begin{array}{c}\text { Died } 5 \text { months } \\
\text { after onset of } \\
\text { symptoms }\end{array}$ \\
\hline $\begin{array}{c}3 \\
(24) \\
{[1996]}\end{array}$ & $39 / \mathrm{M}$ & NA & $\begin{array}{l}\text { Fever, headache, } \\
\text { hemiparesis, } \\
\text { frontal lobe } \\
\text { syndrome }\end{array}$ & $\begin{array}{c}\text { Two } \\
\text { hemispheric } \\
\text { lesions }\end{array}$ & 10 & $\begin{array}{c}\text { Brain biopsy } \\
\text { and PCR on } \\
\text { CSF }\end{array}$ & Foscarnet & $\begin{array}{c}\text { Died } 10 \text { weeks } \\
\text { after onset of } \\
\text { symptoms }\end{array}$ \\
\hline $\begin{array}{c}4 \\
(24) \\
{[1996]}\end{array}$ & $34 / \mathrm{M}$ & Not & $\begin{array}{c}\text { Headache, } \\
\text { hemiparesis, } \\
\text { aphasia, retinitis, } \\
\text { colitis }\end{array}$ & $\begin{array}{c}\text { Single } \\
\text { hemispheric } \\
\text { lesion }\end{array}$ & 9 & Brain biopsy & $\begin{array}{l}\text { Foscarnet and } \\
\text { then Ganciclovir }\end{array}$ & $\begin{array}{c}\text { Died } 6 \text { months } \\
\text { after onset of } \\
\text { symptoms }\end{array}$ \\
\hline $\begin{array}{c}5 \\
(5) \\
{[1997]}\end{array}$ & $31 / \mathrm{M}$ & $\begin{array}{c}\text { Yes } \\
\text { (retinitis) }\end{array}$ & $\begin{array}{c}\text { Headache, } \\
\text { hemiparesis, } \\
\text { dificulty speaking }\end{array}$ & $\begin{array}{c}\text { Single } \\
\text { hemispheric } \\
\text { lesion }\end{array}$ & 10 & Brain biopsy & Ganciclovir & $\begin{array}{l}\text { Alive } 4 \text { months } \\
\text { after discharged } \\
\text { from hospital }\end{array}$ \\
\hline $\begin{array}{c}6 \\
(16) \\
{[1997]}\end{array}$ & $35 / \mathrm{M}$ & Not & $\begin{array}{c}\text { Psychomotor } \\
\text { slowing, facial palsy, } \\
\text { hemiparesis, gait } \\
\text { difficulties }\end{array}$ & $\begin{array}{c}\text { Single } \\
\text { hemispheric } \\
\text { lesion }\end{array}$ & 20 & Brain biopsy & $\begin{array}{l}\text { Ganciclovir and } \\
\text { then foscarnet }\end{array}$ & $\begin{array}{l}\text { Died after } 41 / 2 \\
\text { months of } \\
\text { diagnosis }\end{array}$ \\
\hline $\begin{array}{c}7 \\
(16) \\
{[1997]}\end{array}$ & $51 / \mathrm{M}$ & Yes (colitis) & $\begin{array}{l}\text { Headache, } \\
\text { hemiparesis, } \\
\text { cerebelar syndrome, } \\
\text { disseminated } \\
\text { infection }\end{array}$ & $\begin{array}{l}\text { Single } \\
\text { cerebelar } \\
\text { lesion }\end{array}$ & NA & Necropsy & $\begin{array}{l}\text { Without } \\
\text { treatment }\end{array}$ & $\begin{array}{l}\text { Died } 4 \text { weeks } \\
\text { after admission }\end{array}$ \\
\hline $\begin{array}{c}\text { Our } \\
\text { patient }\end{array}$ & $39 / \mathrm{F}$ & Not & $\begin{array}{c}\text { Fever, seizures, } \\
\text { psychomotor slowing, } \\
\text { pulmonary mass, } \\
\text { perivaginal ulcers }\end{array}$ & $\begin{array}{l}\text { Single, } \\
\text { hemispheric } \\
\text { lesion }\end{array}$ & 8 & Brain biopsy & $\begin{array}{l}\text { Without } \\
\text { treatment }\end{array}$ & $\begin{array}{l}\text { Died } 4 \text { weeks } \\
\text { after admission }\end{array}$ \\
\hline
\end{tabular}

NOTE. NA, not available; M, male; F, female; CMV, cytomegalovirus; CT, computed tomography; MRI, magnetic resonance imaging; CSF, cerebrospinal fluid; $\mathrm{PCR}$, protein chain reaction.

received solid organ transplantation ${ }^{25}$ concluded that combined antiviral therapy with ganciclovir and foscarnet are safe and could possibly benefit those patients harboring ganciclovir-resistant strains. Moreover, combined use of ganciclovir and foscarnet could be more aggressive therapeutic approach due to their presumed synergy ${ }^{9}$. Considering these aspects, some authors suggest the use of combined therapies for central nervous system CMV involvement ${ }^{8,20}$. Interestingly, the only survivor ${ }^{5}$ from the reported cases of cerebral mass lesions due to CMV, had used ganciclovir to treat a neurological complication. The good outcome may be attributed to the early diagnosis, timely treatment, and intravenous secondary prophylaxis.

Current guidelines recommend interventions to prevent recurrences of cytomegalic chorioretinitis, namely, parenteral or oral ganciclovir, parenteral foscarnet or ganciclovir combined with foscarnet ${ }^{17}$. Concerning the late diagnosable intracranial mass lesions, it seems reasonable the use of combined therapy in spite of the additive toxicity. This approach justifies itself when we face the poor prognosis of almost all cases 


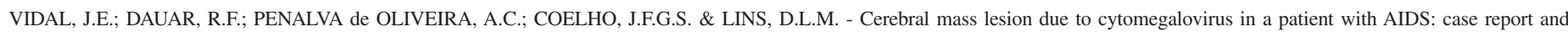
literature review. Rev. Inst. Med. trop. S. Paulo, 45(6):333-337, 2003.

reported. As occurs in other different neurological syndromes observed in AIDS patients, a limited lifespan is anticipated, in general 1-7 months ${ }^{20,21}$

We concluded that CMV disease should be always considered in the differential diagnosis of intracranial mass lesions in AIDS patients, mostly in those severely immunodepressed and previous or concomitant cytomegalic infection in other organ. High suspicion index, timely diagnostic procedures (surgical or minimally invasive), and proper utilization of prophylactic and therapeutic medication could improve outcome of these patients.

\section{RESUMO}

\section{Lesão expansiva cerebral devida a citomegalovírus: relato de caso e revisão da literatura}

As doenças causadas pelo citomegalovírus (CMV) em pacientes com a síndrome da imunodeficiência adquirida apresentam-se principalmente como corioretinite ou comprometimento gastrointestinal. No sistema nervoso central, o CMV pode causar diversas síndromes clínicas: poliradiculite, mielite, encefalite, ventrículo-encefalite e mononeurite múltipla. Raramente, lesões expansivas cerebrais são descritas. Os autores relatam o caso de uma paciente de 39 anos com antecedentes de infecção pelo HIV e toxoplasmose cerebral, que apresentou-se com febre, convulsões e úlceras vulvares. O raios-X de tórax demonstrou múltiplos nódulos pulmonares e a tomografia computadorizada de crânio evidenciou extensa lesão no lobo frontal esquerdo. Após ser submetida à craniotomia, evoluiu com piora clínica, falecendo no primeiro dia de pós-operatório. Os estudos histopatológicos e imunohistoquímicos demonstraram doença citomegálica. Foram excluídas toxoplasmose cerebral e infecção bacteriana, micobacteriana ou fúngica. Concluímos que, embora seja extremamente raro, o CMV deve ser considerado no diagnóstico diferencial das lesões expansivas cerebrais em pacientes com infecção pelo HIV. Um elevado índice de suspeita, procedimentos diagnósticos oportunos (cirúrgicos ou minimamente invasivos), e o adequado uso de antivirais (terapêuticos e profiláticos) podem melhorar o prognóstico desta letal manifestação.

\section{REFERENCES}

1. AMMASSARI, A.; CINGOLANI, A.; PEZZOTI, P. et al. - AIDS-related focal brain lesions in the era of highly active antiretroviral therapy. Neurology, 55: 1194-1200, 2000 .

2. AMERICAN ACADEMY OF NEUROLOGY - Evaluation and management of intracranial mass lesion in AIDS. Report of the Quality Standars Subcommittee of the American Academy of Neurology. Neurology, 50: 21-26, 1998.

3. ANDUZE-FARIS, B.M.; FILLET, A.M.; GOZLAN, J. et al. - Induction and maintenance therapy of cytomegalovirus central nervous system infection in HIV-infected patients. AIDS, 14: 517-524, 2000.

4. ARRIBAS, J.R.; STORCH, G.A.; CLIFFORD, D.B. \& TSELIS, A.C. - Cytomegalovirus encephalitis. Ann. intern. Med., 125: 577-587, 1996.

5. BASSIL, H.F. \& WILLIAM, D.C. - Cytomegalovirus encephalitis in an HIV positive patient presenting with a cerebral mass lesion. AIDS Patient Care STDS, 11: 319321, 1997.

6. BERMAN, S.M. \& KIM, R.C. - The development of cytomegalovirus encephalitis in AIDS patients receiving ganciclovir. Amer. J. Med., 96: 415-419, 1994.
7. BURNS, D.K.; RISSER, R.C. \& WHITE, C.L. - The neuropathology of human immunodeficiency virus infection. The Dallas, Texas, experience. Arch. Path. Lab. Med., 115: 1112-1124, 1991.

8. CINQUE, P.; CLEATOR, G.M.; WEBER, T. et al. - Diagnosis and clinical management of neurological disorders caused by cytomegalovirus in AIDS patients. European Union Concerted Action on Virus Meningitis and Encephalitis. J. Neurovirol., 4: 120-132, 1998.

9. DIETERICH, D.T.; POLES, M.A.; LEW, E.A. et al. - Concurrent use of ganciclovir and foscarnet to treat cytomegalovirus infection in AIDS patients. J. infect. Dis., 167: 1184-1188, 1993.

10. DYER, J.R.; FRENCH, M.A. \& MALLAL, S.A. - Cerebral mass lesions due to cytomegalovirus in patients with AIDS: report of two cases. J. Infect., 30: 147-151, 1995.

11. GALLANT, J.E.; MOORE, R.D.; RICHMAN, D.D.; KERULY, J. \& CHAISSON, R.E. - Incidence and natural history of cytomegalovirus disease in patients with advanced human immunodeficiency virus disease treated with zidovudine. The Zidovudine Epidemiology Study Group. J. infect. Dis., 166: 1223-1227, 1992.

12. GIMÉNEZ BASCUÑANA, A. - Aparencia pseudoneoplasica de la infección citomegálica del tracto digestivo. Rev. clin. esp., 198: 848-850, 1998.

13. GRASSI, M.P.; CLERICI, F.; PERIN, C. et al. - Microglial nodular encephalitis and ventriculoencephalitis due to cytomegalovirus infection in patients with AIDS: two distinct clinical patterns. Clin. infect. Dis., 27: 504-508, 1998.

14. GRAY, F.; CHRÉTIEN F.; VALLAT-DECOUVELAERE, A.V. \& SCARAVILLI, F. The changing pattern of HIV neuropathology in the HAART era. J. Neuropath. exp. Neurol., 62: 429-440, 2003.

15. HOLLAND, N.R.; POWER, C.; MATHEWS, V.P. et al. - Cytomegalovirus encephalitis in acquired immunodeficiency syndrome (AIDS). Neurology, 44: 507-514, 1994.

16. HUANG, P.P., McMEEKING, A.A.; STEMPIEN, M.J. \& ZAGZAG, D. Cytomegalovirus disease presenting as a focal brain mass: report of two cases. Neurosurgery, 40: 1074-1078, 1997.

17. KAPLAN, J.E.; MASUR, H.E. \& HOLMES, K.K. - Guidelines for preventing opportunistic infections among HIV-infected persons - 2002. Recommendations of the U.S. Public Health Service and the Infectious Disease Society of America. M. M. W. R., 51 (RR-8): 1-52, 2002.

18. KURE, K.; LLENA, J.F.; LYMAN, W.D. et al. - Human immunodeficiency virus-1 infection of the nervous system: an autopsy study of 268 adult, pediatric, and fetal brains. Human Path., 22: 700-710, 1991.

19. MARINS, J.R.; JAMAL, L.F.; CHEN, S.Y. et al. - Dramatic improvement in survival among adult Brazilian AIDS patients. AIDS, 17: 1675-1682, 2003.

20. MASCHKE, M.; KASTRUP, O. \& DIENER, H.C. - CNS manifestations of cytomegalovirus infections: diagnosis and treatment. CNS drugs, 16: 303-315, 2002.

21. McCUTCHAN, J.A. - Cytomegalovirus infections of the nervous system in patients with AIDS. Clin. infect. Dis., 20: 747-754, 1995.

22. McGUINNES, G.; SCHOLES, J.V.; GARAY, S.M. et al. - Cytomegalovirus pneumonitis: spectrum of parenquimal CT findings with pathologic correlation in 21 AIDS patients. Radiology, 192: 451-459, 1994.

23. McKENZIE, R.; TRAVIS, W.D.; DOLAN, S.A. et al. - The causes of death in patients with human immunodeficiency virus infection: a clinical and pathologic study with emphasis on the role of pulmonary diseases. Medicine (Baltimore), 70: 326-343, 1991.

24. MOULIGNIER, A.; MIKOL, J.; GONZALEZ-CANALI, G. et al. - AIDS-associated cytomegalovirus infection mimicking central nervous system tumors: a diagnosis challenge. Clin. infect. Dis., 22: 626-631, 1996. 


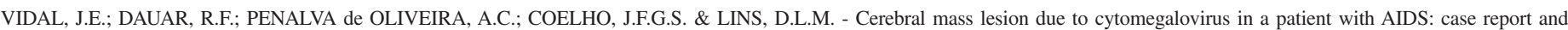
literature review. Rev. Inst. Med. trop. S. Paulo, 45(6):333-337, 2003.

25. MYLONAKIS, E.; KALLAS, W.M. \& FISHMAN, J.A. - Combination antiviral therapy for ganciclovir-resistant cytomegalovirus infection in solid organ transplant recipients. Clin. infect. Dis., 34: 1337-1341, 2002.

26. NAVIA, B.A.; CHO, E.S.; PETITO, C.K. \& PRICE, R.W. - The AIDS dementia complex: II. Neuropathology. Ann. Neurol., 19: 525-535, 1986.

27. NORTHFELT, D.W.; SOLLITTO, R.A.; MILLER, T.R. \& HOLLANDER, H. Cytomegalovirus pneumonitis. An unusual cause of pulmonary nodules in a patient with AIDS. Chest, 103: 1918-1920, 1993.

28. RICH, J.D.; CRAWFORD, J.M.; KAZANJIAN, S.N. \& KAZANJIAN, P.H. - Discrete gastrointestinal mass lesions caused by cytomegalovirus in patients with AIDS: report of three cases and review. Clin. infect. Dis., 15: 609-614, 1992.
29. SCHELLENBERG, D.M; DESMOND, N.M.; MURPHY, S.M. \& TANNER, A.G. AIDS-associated cytomegalovirus infection of the submandibular gland mimicking a tumour. J. roy. Soc. Med., 87: 483-484, 1994.

30. SKIEST, D.J. - Focal neurological disease in patients with acquired immunodeficiency syndrome. Clin. infect. Dis., 34: 103-115, 2002.

31. TINELLI, M.; CASTELNUOVO, P.; PANIGAZZI, A.; D'ANDREA, F. \& CAPRIOGLIO, S. - Mass lesions of the larynx due to cytomegalovirus infection in a patient infected with the human immunodeficiency virus. Clin. infect. Dis., 20: 726-727, 1995.

Received: 10 September 2003

Accepted: 12 November 2003 